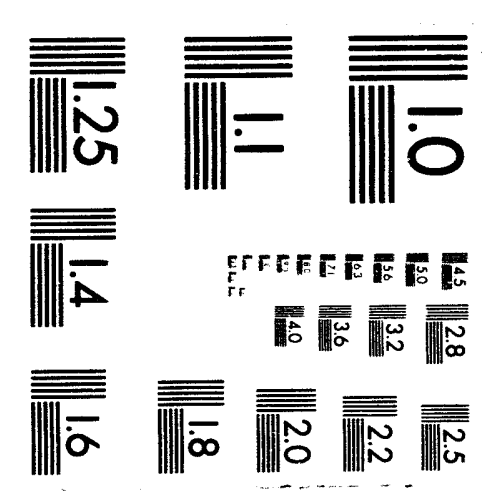



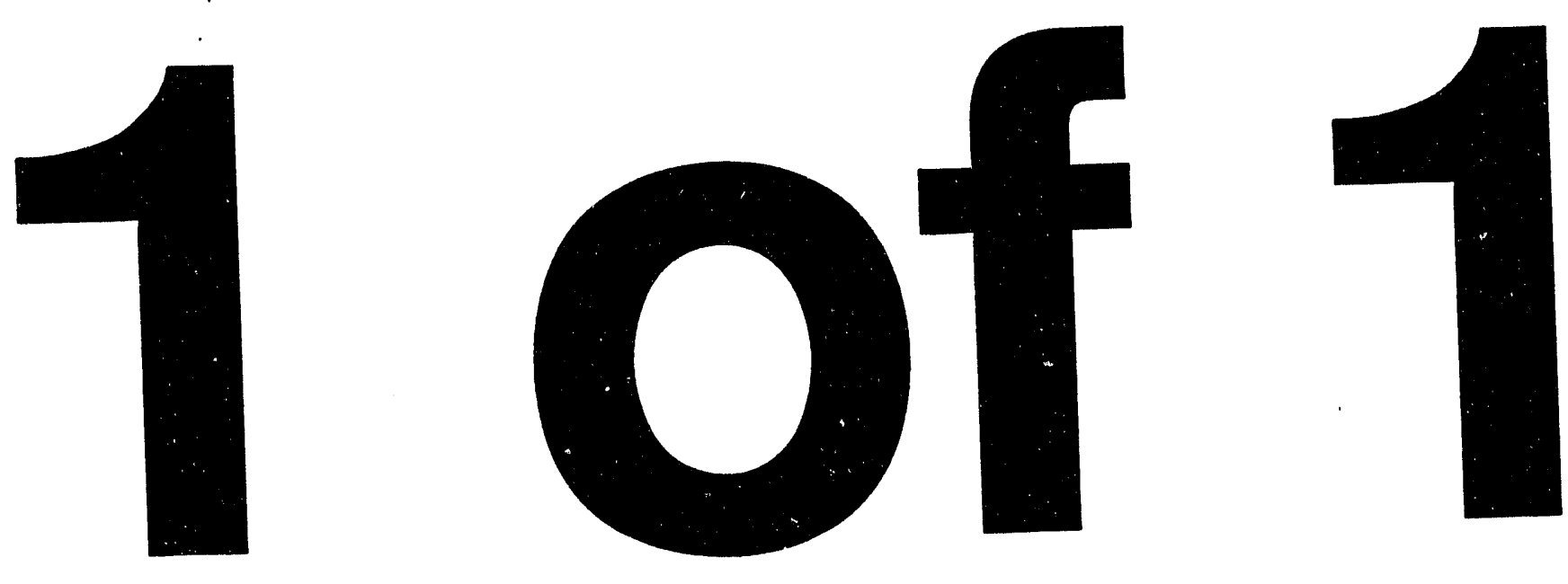


\title{
Characterization and Reaction Behavior of Ferrocyanide Simulants and Hanford Site High-Level Ferrocyanide Waste
}

\author{
D. W. Jeppson \\ B. C. Simpson
}

Date Published

February 1994

To Be Presented at

Waste Management 1994

Tucson, Arizona

February 27 - March 3, 1994

Prepared for the U.S. Department of Energy Office of Environmental Restoration and Waste Management

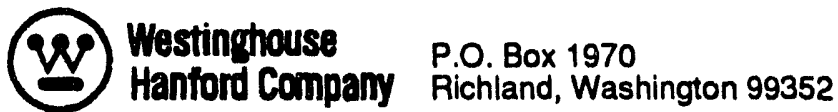

Hanford Operations and Engineering Contractor for the U.S. Department of Energy under Contract DE-AC06-87RL10930

Copyright License By acceptance of this articlo, the publisher and/or recipient acknowledgen the U.S. Government's right to rotain a nonoxclusive, royally-free liconses in and to any copyright covoring this paper. 


\title{
CHARACTERIZATION ND REACTION BEHAVIOR OF FERROCYANIDE SIMULANTS AND HANFORD SITE HIGH-LEVEL FERROCYANIDE MASTE
}

\author{
David W. Jeppson and Brett C. Simpson \\ Westinghouse Hanford Company
}

\section{ABSTRACT}

Nonradioactive waste simulants and initial ferrocyanide tank waste samples were characterized to assess potential safety concerns associated with ferrocyanide high-level radioactive waste stored at the Hanford Site in underground single-shell tanks (SSTs). The simulants were prepared to represent wastes added to the tanks during the 1950s. Chemical, physical, thermodynamic, and reaction properties of the waste simulants were determined and compared to properties of initial samples of actual ferrocyanide wastes presently in the tanks. The simulants, "as-prepared," were shown to not support propagating reactions when subjected to a strong ignition source. The simulant with the greatest ferrocyanide concentration was shown to not support a propagating reaction that would involve surrounding waste because of its high water content. Evaluation of dried simulants indicated a concentration limit of about 14 wt\% disodium mononickel ferrocyanide, below which propagating reactions could not occur in the ambient temperature buik tank waste. For postulated localized hot spots where dried waste is postulated to be at an initial temperature of $130{ }^{\circ} \mathrm{C}$, a concentration limit of about 13 wt\% disodium mononickel ferrocyanide was determined, below which propagating reactions could not occur.

Analyses of initial samples of the presently stored ferrocyanide waste indicate that the waste tank ferrocyanide concentrations are considerably lower than the limit for propagation for dry waste and that the water content is near that of the as-prepared simulants. The remaining tanks are being sampled and analyzed for evaluation on an individual tank basis. If the initial trend continues, it will be possible to show that runaway ferrocyanide reactions are not possible under present tank conditions. The lower ferrocyanide concentrations in actual tank waste may be due to tank waste mixing and/or degradation from radiolysis and/or hydrolysis, which may have occurred over approximately 35 years of storage.

Ferrocyanide waste presently in Hanford Site underground storage tanks has recently been classified as "safe" [ $\mathrm{Na}_{2} \mathrm{NiFe}(\mathrm{CN})_{6}$ concentration of $\leq 8 \mathrm{wt} \%$ ] or "conditionally safe" [water is present at $\geq 0$ to 24 wt\% when $\mathrm{Na}_{2} \mathrm{NiFe}(\mathrm{CN})_{6}$ is present at $>8 \mathrm{wt} \%$, and the waste temperature is $\left.\leq 90^{\circ} \mathrm{C}\right]$. (1) Additional tank waste sampling to identify existing ferrocyanide concentrations, water content, and potential chemical reaction energy release on heating are continuing. Moisture retention studies with simulants to resolve outstanding safety concerns associated with postulated dryout are continuing. Results of these ongoing activities will be used to evaluate the likely possibility that all ferrocyanide waste will be categorized as "safe."

\footnotetext{
"Free-water content. The moisture criterion increases linearly from 0 wt\% at 8 wt\% fuel to 24 wt\% at 26 wt\% fuel.
} 


\section{INTRODUCTION AND BACKGROUND}

A large quantity of sodium (and some potassium) ferrocyanide [about 140 metric tons of $\mathrm{Fe}(\mathrm{CN})_{6}^{-4}$ ] was used at the Hanford Site in the $1950 \mathrm{~s}$ to remove radioactive cesium, strontium, and cobalt from liquid and slurry wastes. Most of this ferrocyanide formed insoluble metal complexes, which were precipitated in underground storage tanks (750,000-gal SSTs) as sludge mixtures combined with nitrate/nitrite oxidants and inert diluents. A schematic of a typical SST and stored waste is shown in Figure 1 . The decontaminated supernatants from this scavenging process were discharged to soil columns to minimize SST tank storage space requirements. Using historical process records, 18 tanks at the Hanford Site were determined to have received $1,000 \mathrm{~g}$ moles or more of ferrocyanide (mostly as disodium mononickel ferrocyanide).

Pure, near stoichiometric mixtures of ferrocyanide salts and nitrate/ nitrite oxidants can explode under specific conditions of (1) externally heating to high temperatures (above $250^{\circ} \mathrm{C}$ ) or (2) by an electrical spark of sufficient energy to ignite a dry mixture. (2) The potential for rapid, uncontrolled chemical reactions of impure mixtures of ferrocyanide and nitrate/nitrite as formed in the ferrocyanide waste tanks was not known. In October 1990, the hazard posed by potential exothermic reactions between ferrocyanides and oxidizers in this high-level waste was declared an unreviewed safety question (USQ). (3) With this declaration, activities with the ferrocyanide waste tanks, such as tank waste sampling, have been highly restricted. It became necessary to use representative simulants along with limited tank waste sampling to help assess safety concerns of the ferrocyanide waste. The work reported herein is directed toward supporting closure of the ferrocyanide USQ and resolving the safety issue associated with the Hanford Site ferrocyanide waste tanks.

\section{SIMULANTS REPRESENTING AS-PREPARED HANFORD SITE WASTE}

\section{Ferrocyanide Waste Types}

Simulants were prepared to represent the various Hanford Site ferrocyanide wastes formed in the SSTs. The flowsheets used to produce these waste types are termed U Plant, T Plant, and In Farm. ${ }^{(4)}$ Scavenging treatments varied as functions of feed composition, process development, and chemicals available for treatment at a given time. Two variations each of the $U$ Plant and In Farm simulants were prepared to represent waste that had the greatest ferrocyanide concentration (U PIant 2 and In Farm 1 ) and waste that would have a more typical ferrocyanide concentration (U Plant 1 and In Farm 2). Sodium ferrocyanide (potassium ferrocyanide for initial U Plant batches) was added to the waste along with equimolar quantities of nickel sulfate to scavenge ${ }^{137} \mathrm{Cs}$ and ${ }^{90} \mathrm{Sr}$. Calcium nitrate (strontium nitrate for most $U \mathrm{Pl}$ ant batches) was added to the waste when enhanced strontium scavenging was needed. Sodium sulfide was added to some of the In Farm wastes with near equimolar quantities of nickel sulfate to enhance the scavenging of radioactive cobalt from the waste on an as-needed basis. Calcium nitrate, when added to the waste, would form an inert diluent, such as insoluble calcium sulfate or phosphate. Sodium sulfide reacts with the nickel sulfate, also added to the waste to form insoluble nickel sulfide, which is a fuel in the presence of an oxidant. The fractions of ferrocyanide used and the scavenging treatments 
used at the Hanford Site are 1 isted in Table 1 along with the representative simulants. The variations not represented directly by a simulant were expected to be less reactive than one or both of the simulants for that waste type.

Tabie 1. Scavenging Treatments Used and Representative Simulants of Hanford Waste.

\begin{tabular}{|c|c|c|c|c|}
\hline \multirow[b]{2}{*}{ Simulant } & \multirow{2}{*}{$\begin{array}{c}\text { Representative } \\
\text { percentage of } \\
\text { total Hanford } \\
\text { ferrocyanide } \\
\text { used }\end{array}$} & \multicolumn{3}{|c|}{ Chemicals added for scavenging treatment } \\
\hline & & $\begin{array}{l}\text { Ferrocyanide } \\
\text { for CS }(M)\end{array}$ & $\begin{array}{c}\text { Sodium sulfide } \\
\text { for } \\
\mathrm{CO}^{\circ}(\mathrm{M})\end{array}$ & $\begin{array}{l}\text { Calcium or } \\
\text { strontium } \\
\text { nitrate for } \\
{S r^{b}} \text { (M) }\end{array}$ \\
\hline $\begin{array}{l}\text { U Plant } \\
\text { U Plant } 1 \\
\text { U Plant } 2\end{array}$ & $\begin{array}{l}46 \\
10 \\
10\end{array}$ & $\begin{array}{l}0.0025 \\
0.005 \\
0.005\end{array}$ & $\begin{array}{l}\text { None } \\
\text { None } \\
\text { None }\end{array}$ & $\begin{array}{l}0.004 \mathrm{Sr} \\
\text { None } \\
0.016 \mathrm{Ca}\end{array}$ \\
\hline T Plant & 8 & 0.005 & None & None \\
\hline $\begin{array}{l}\text { In Farm } \\
\text { In Farm } 1\end{array}$ & $\begin{array}{c}1 \\
2 \\
1 \\
2 \\
5 \\
12 \\
1 \\
1 \\
1 \\
0\end{array}$ & $\begin{array}{l}0.0075 \\
0.0075 \\
0.005 \\
0.005 \\
0.005 \\
0.005 \\
0.005 \\
0.005 \\
0.0025 \\
\text { None }\end{array}$ & $\begin{array}{l}0.003 \\
0.003 \\
0.003 \\
\text { None } \\
0.0025-0.006 \\
\text { None } \\
0.003 \\
\text { None } \\
\text { None } \\
0.003-0.0045\end{array}$ & $\begin{array}{l}\text { None } \\
0.01 \mathrm{Ca} \\
\text { None } \\
\text { None } \\
0.01 \mathrm{Ca} \\
0.01 \mathrm{Ca} \\
0.02 \mathrm{Ca} \\
0.03 \mathrm{Ca} \\
\text { None } \\
0.02 \mathrm{Ca}\end{array}$ \\
\hline
\end{tabular}

"NaS was added with nickel sulfate for batches indicated to aid in precipitation of ${ }^{60} \mathrm{CO}$ and $\mathrm{COS}$.

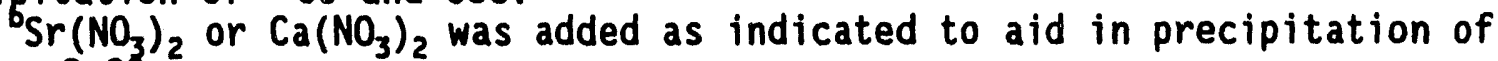
${ }^{90} \mathrm{Sr}$ as $\mathrm{SrSO}_{4}$.

Three main adjustments from the actual processes used in the 1950s were made in preparing simulants thought to more nearly represent ferrocyanide waste stored in SSTs today and to provide simulants that were not radioactive.

- The solution concentrations (except $U$ Plant 1 ) were adjusted to include nitrite at a $1: 3$ mole ratio of nitrite/nitrate to account for nitrite buildup over time in the wastes by radiolysis of nitrate. Nitrite is more exothermic when reacting with ferrocyanide than nitrate, and the mixture is expected to react at a lower temperature. 
- The radioactive isotopes in actual tank waste were not included in the simulant because of the difficulty in working with radioactive materials.

- The settled waste simulants from the laboratory scavenging process were centrifuged at a force of $2,500 \mathrm{~g}$ to mimic an equivalent 30 gravity-year settling period.

\section{Physical Properties}

Physical property measurements were made on the ferrocyanide simulants prepared. The simulant volume fraction produced, simulant density, simulant permeability, and supernatant density are listed in Table 2.

Table 2. Physical Properties of Ferrocyanide Simulants and Their Supernatants.

\begin{tabular}{|l|c|c|c|c|}
\hline Simulant & $\begin{array}{c}\text { Supernatant } \\
\text { densityy } \\
\left(\mathrm{g} / \mathrm{cm}^{3}\right)\end{array}$ & $\begin{array}{c}\text { Fraction of } \\
\text { simulant per } \\
\text { volume of feed } \\
\text { solution }\end{array}$ & $\begin{array}{c}\text { Simulant } \\
\text { density } \\
\left(\mathrm{g} / \mathrm{cm}^{3}\right)\end{array}$ & $\begin{array}{c}\text { Permeability } \\
(\mathrm{cm} / \mathrm{s})\end{array}$ \\
\hline U Plant 1 & 1.21 & 0.036 & 1.40 & $5.6 \times 10^{-6}$ \\
U P1ant 2 & 1.21 & 0.043 & 1.27 & --- \\
T P1 ant & 1.13 & 0.038 & 1.35 & --- \\
In Farm 1 & 1.33 & 0.013 & 1.49 & $4.0 \times 10^{-7}$ \\
\hline In Farm 2 & 1.27 & 0.010 & 1.39 & - \\
\hline
\end{tabular}

\section{Chemical Composition}

The chemical composition of the simulants are listed in Table 3 on a dry-weight basis. Most of the simulants were divided into a top and bottom fraction by color difference, and each fraction was analyzed separately. The volume fraction of top-fraction material is listed in the table heading, and the bottom fraction consists of the remaining material. It should be noted that there is sufficient oxidant (nitrate/nitrite) present in all simulants to react with all of the cyanide present in the respective simulant. The In Farm 1 simulant also contains a small amount of sulfide fuel. A small quantity of cesium was added to the in Farm simulants to support aerosol release tests on these simulants. To convert the reported cyanide analysis to $\mathrm{Na}_{2} \mathrm{NiFe}(\mathrm{CN})_{6}$, multiply the cyanide analysis by 2.03. The free-water content of the as-prepared (centrifuged) simulants is also reported at the bottom of Table 3 .

Bound water (water remaining in the dried simulant after heating to $60{ }^{\circ} \mathrm{C}$ under vacuum for 18 hours) held in the dried waste as adsorbed and as hydrated water was quantified to be about 4.6 moles of water per mole of ferrocyanide. This bound water content of dried simulants was determined by conducting simultaneous differential scanning calorimeter (DSC), thermogravimetric 
Table 3. Chemical Composition of Simulants.

\begin{tabular}{|c|c|c|c|c|c|}
\hline \multirow{3}{*}{ Analyte } & \multicolumn{5}{|c|}{ Simulant and simulant fraction } \\
\hline & U Plant 1 & $\begin{array}{l}\text { U Plant } 2 \\
\text { top }(50 \%) \\
\text { bottom }\end{array}$ & $\begin{array}{l}\text { T Plant } \\
\text { top }(90 \%) \\
\text { bottom }\end{array}$ & $\begin{array}{l}\text { In Farm } 1 \\
\text { top }(40 \%) \\
\text { bottom }\end{array}$ & $\begin{array}{l}\text { In Farm } 2 \\
\text { top }(50 \%) \\
\text { bottom }\end{array}$ \\
\hline & \multicolumn{5}{|c|}{ Composition, wt\% on dry weight basis } \\
\hline Bound water & $1.2^{\circ}$ & $\begin{array}{l}2^{\circ} \\
2.5\end{array}$ & $1^{3}$ & $\begin{array}{l}5.8 \\
5.4\end{array}$ & $\begin{array}{l}5.6 \\
5.9^{\circ}\end{array}$ \\
\hline Nitrate & 49 & $\begin{array}{l}37.0 \\
33.0\end{array}$ & $\begin{array}{c}19.3 \\
3.89\end{array}$ & $\begin{array}{l}29.1 \\
29.0\end{array}$ & $\begin{array}{l}27.1 \\
24.7\end{array}$ \\
\hline Nitrite & -- & $\begin{array}{l}8.02 \\
7.29 \\
\end{array}$ & $\begin{array}{l}4.76 \\
0.91 \\
\end{array}$ & $\begin{array}{l}8.21 \\
7.58 \\
\end{array}$ & $\begin{array}{l}7.26 \\
6.28 \\
\end{array}$ \\
\hline Sulfate & 5.5 & $\begin{array}{l}4.8 \\
4.4\end{array}$ & $\begin{array}{l}1.65^{b} \\
0.45^{b}\end{array}$ & $\begin{array}{l}3.3 \\
3.3\end{array}$ & $\begin{array}{l}2.4 \\
2.3\end{array}$ \\
\hline Phosphate & 3.1 & $\begin{array}{l}8.0 \\
8.9 \\
\end{array}$ & $\begin{array}{l}18.4^{c} \\
27.6^{c}\end{array}$ & $\begin{array}{l}10^{d} \\
10^{d}\end{array}$ & $\begin{array}{l}5.8 \\
7.6 \\
\end{array}$ \\
\hline Cyanide & 2.3 & $\begin{array}{l}3.1 \\
4.1\end{array}$ & $\begin{array}{l}4.33 \\
0.795\end{array}$ & $\begin{array}{r}9.0 \\
12.6\end{array}$ & $\begin{array}{r}9.1 \\
11.1\end{array}$ \\
\hline Sulfide & --- & --- & $-\cdots$ & $\begin{array}{l}0.6^{\circ} \\
1.3^{\circ} \\
\end{array}$ & $-\cdots$ \\
\hline Sodium & 31.4 & $\begin{array}{l}23 \\
21\end{array}$ & $\begin{array}{l}19 \\
3.5\end{array}$ & $\begin{array}{l}17 \\
16.6\end{array}$ & $\begin{array}{l}22 \\
20 \\
\end{array}$ \\
\hline Iron & 7.6 & $\begin{array}{l}6 \\
7\end{array}$ & $\begin{array}{l}9.8 \\
2.3\end{array}$ & $\begin{array}{l}3.5 \\
4.9\end{array}$ & $\begin{array}{l}3.8 \\
4.0\end{array}$ \\
\hline Nickel & 0.87 & $\begin{array}{l}1.4 \\
1.8\end{array}$ & $\begin{array}{l}1.95 \\
0.36\end{array}$ & $\begin{array}{l}5.0 \\
6.8 \\
\end{array}$ & $\begin{array}{l}4.1 \\
4.5\end{array}$ \\
\hline Cesium & --- & --- & $\begin{array}{l}0.100 \\
0.0125\end{array}$ & $\begin{array}{l}0.30 \\
0.42 \\
\end{array}$ & $\begin{array}{l}0.46 \\
0.50\end{array}$ \\
\hline Other inerts & 8.4 & $\begin{array}{r}7 \\
11\end{array}$ & $\begin{array}{l}17.7 \\
59.2^{f}\end{array}$ & $\begin{array}{l}8.5 \\
2.4\end{array}$ & $\begin{array}{l}12.4 \\
13.1\end{array}$ \\
\hline Free water & 66 & $\begin{array}{l}67 \\
64\end{array}$ & $\begin{array}{l}69 \\
45\end{array}$ & $\begin{array}{l}51 \\
48\end{array}$ & $\begin{array}{l}52 \\
50\end{array}$ \\
\hline
\end{tabular}

Estimated based upon ferrocyanide content (4.6 mole water per mole of ferrocyanide).

${ }^{6} \mathrm{Calculated}$ from inductively coupled plasma (ICP) and X-ray

fluorescence (XRF) sulfur analysis assuming all sulfur is sulfate.

${ }^{c}$ Calculated from ICP and XRF phosphorus analysis assuming all phosphorus is phosphate.

Adjusted values from analysis to make material balance.

'Calculated from feed make up.

fBismuth is 39 wt\%. 
analysis (TGA), and mass spectrometry on released gases. This bound water is important to safety because endotherms associated with its loss at higher temperatures can play a role in preventing propagating reactions in dried ferrocyanide waste.

These analytical results indicate that the In Farm simulants contained the greatest concentration of cyanide with the In Farm 1 bottom fraction containing the most [12.6 wt\% $\mathrm{CN}$ or 25.6 wt\% $\left.\mathrm{Na}_{2} \mathrm{NiFe}(\mathrm{CN})_{6}\right]$ and a small amount of sulfide fuel (1.3 wt\%). The In Farm simulants contained about 50 wt\% free water and significant bound water. The residual mass consisted of nitrate/ nitrite oxidant and inert solid diluents.

\section{REACTION PROPERTIES OF AS-PREPARED SIMULANTS}

No propagating reactions occurred for the as-prepared simulants even when subjected to a strong ignition source (heating to greater than $1,200{ }^{\circ} \mathrm{C}$ ). The reaction of the ferrocyanide and oxidant present in the as-prepared simulants was insufficient to provide the necessary heat to overcome the heat of vaporization of the water present in the simulants and sustain a reaction.

\section{REACTION PROPERTIES OF DRIED IN FARN SIMULANTS}

Reaction tests were conducted with dried In Farm 1, bottom-fraction simulant to determine propagation rates, energy releases, reaction products formed, and aerosol production for the disodium mononickel ferrocyanide reaction with nitrate/nitrite oxidant in a waste matrix. Dried In Farm 1, bottom-fraction simulant was tested because it had the highest ferrocyanide concentration [25.6 wt\% $\mathrm{Na}_{2} \mathrm{NiFe}(\mathrm{CN})_{6}$ ] of all the simulants prepared and was most likely to react io completion. Parametric tests were conducted as functions of ferroc inide concentration, initial test temperature, initial test pressure, water concentration, geometry, and density. Tests were conducted by igniting a vertical test cylinder of prepared simulant at the top open end in a containment vessel in an argon atmosphere. The rate of propagation was measured by monitoring the temperature responses of imbedded thermocouples as a function of time. $(5,6)$ A typical propagation rate test configuration used is shown in Figure 2.

\section{Dependence on Ferrocyanide, Hater, and Solid Diluent Content}

Adiabatic calorimeter and propagation test results are shown in Figure 3 to illustrate the effects of water, solid diluents, and ferrocyanide concentration on propagation limits of dried ambient temperature (initial temperature 25 to $30^{\circ} \mathrm{C}$ ) waste. These results indicate that propagating reactions will not occur for dry waste concentrations of 14 wt\% $\mathrm{Na}_{2} \mathrm{NiFe}(\mathrm{CN})_{6}$ or less. These results also indicate that for the most concentrated dried ferrocyanide simulant [25.6 wt\% $\mathrm{Na}_{2} \mathrm{NiFe}(\mathrm{CN})_{6}$ ] that a water content of $12 \mathrm{wt} \%$ or greater is sufficient to prevent a propagating reaction from occurring to involve surrounding waste. Propagation tests conducted at an initial temperature of $130^{\circ} \mathrm{C}$ (results not shown in Figure 3 ) indicate a concentration limit of 13 wt\% $\mathrm{Na}_{2} \mathrm{NiFe}(\mathrm{CN})_{6}$, below which propagating reactions will not occur. 
WHC-SA-2190-FP

Dependence on Other Parameters

Measured propagation rates are shown in Figure 4 to illustrate the effects of initial temperature and initial pressure on the most concentrated dried simulant (In Farm 1, bottom fraction). The propagation rates were shown to be dependent upon test cylinder diameter up to $25 \mathrm{~mm}$ diameter. The propagation rate was dependent upon density of the test material. The particle size of the test material was also thought to be significant with the smaller particle sizes reacting at a greater rate; therefore, tests were conducted with very fine particle sizes similar to tank waste.

\section{Reaction Mechanism}

Analyses of solid and gas reaction products of dry In Farm 1, bottomfraction reaction tests help identify the actual chemical reactions occurring when ferrocyanide reacts with nitrate/nitrite oxidant. Gases produced for a test conducted with $49.7 \mathrm{~g}$ of dried In Farm 1, bottom-fraction simulant loaded in a test cylinder $25 \mathrm{~mm}$ in diameter by $80 \mathrm{~mm}$ long at $1.26 \mathrm{sp} \mathrm{gr}$ at an initial pressure of 10.2 atmospheres absolute and an initial test material temperature of $61{ }^{\circ} \mathrm{C}$ in a $49-L$ containment vessel were sampled and analyzed. Results of the sample analyses indicated 5.5 moles nitrogen per mole of ferrocyanide, 2.12 moles of carbon dioxide per mole of ferrocyanide, and 2.60 moles of nitrogen oxide (NO) per mole of ferrocyanide were produced. Other similar tests conducted at initial pressures of about 3 atmospheres indicated similar gas reaction products. The solid reaction products were determined by $X$-ray diffraction (XRD) to include $\mathrm{NaFeO}_{2}$ as a major component and $\mathrm{NaFeO}_{3}, \mathrm{Na}_{2} \mathrm{CO}_{3}$ (with and without one water of hydration), $\mathrm{NaNO}_{2}, \mathrm{NaNO}_{3}, \mathrm{NaAlO}_{2}$, and $\mathrm{NaAl}_{2} \mathrm{O}_{4}$ as minor components. The aluminum came from the igniter materiaf used to ignite the dried test simulant. Inductively coupled plasma and X-ray fluorescence results indicate that only very smal1 amounts of nitrate (about 1.5 wt\% of original nitrate) and nitrite (about 2.4 wt\% of original nitrite) remained in the reaction products. The approximate overall chemical reaction as determined by reaction products is:

$$
\begin{gathered}
\mathrm{Na}_{2} \mathrm{NiFe}(\mathrm{CN})_{6}+6 \mathrm{NaNO}_{3}+2 \mathrm{NaNO}_{2} \rightarrow \\
0.7 \mathrm{NaFeO}_{2}+3.8 \mathrm{Na}_{2} \mathrm{CO}_{3}+\mathrm{Na}_{2} \mathrm{O}+0.3 \mathrm{Ni}_{3} \mathrm{Fe}+2.2 \mathrm{CO}_{2}+2.6 \mathrm{NO}+5.6 \mathrm{~N}_{2} .
\end{gathered}
$$

The overall heat of reaction of the ferrocyanide-nitrate/nitrite reaction at temperatures up to $620^{\circ} \mathrm{C}$ was measured during a U Plant 2 simulant test

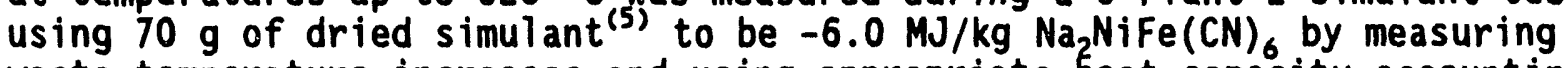
waste temperature increases and using appropriate heat capacity accounting for constituents. A value of $-6.1 \mathrm{MJ} / \mathrm{kg} \mathrm{Na}_{2} \mathrm{NiFe}(\mathrm{CN})_{6}$ was measured from a test $\left.{ }^{6}\right)$ on In Farm 1 simulant. This net energy release appears consistent with theoretical exothermic values reported by Burger for reactions giving $\mathrm{N}_{2}$ and $\mathrm{CO}_{2}$ as gas reaction products -9.5 and $-11.7 \mathrm{MJ} / \mathrm{kg}$ of $\mathrm{Na}_{2} \mathrm{NiFe}(\mathrm{CN})_{6}{ }^{(7)}$ for reaction with nitrate and nitrite, respectively, and an endothermic value of $+2.0 \mathrm{MJ} / \mathrm{kg}$ of $\mathrm{Na}_{2} \mathrm{NiFe}(\mathrm{CN})_{8}$ when $\mathrm{NO}$ is produced along with $\mathrm{N}_{2}$ and $\mathrm{CO}_{2}$ from reactions with nitrate. 
Aerosol releases were determined in similar tests using dried In Farm 1, bottom-fraction simulant. Sodium and cesium were the major cation species released as aerosol from reactions of the dried simulant. The fractions of cesium released from the tests were determined to be 14 wt\% for the $61{ }^{\circ} \mathrm{C}$ initial temperature test and 22 wt\% for the $120{ }^{\circ} \mathrm{C}$ initial temperature test. These values were determined by summing the following: (1) aerosol collected on filter papers, (2) deposition plated on aluminum foil lining (top, sides, and bottom) of the reaction chamber, and (3) loose deposits at the bottom of the reaction chamber at the completion of the test. The percentages (61 and 72\%) of the released cesium were collected as aerosol on the filters from vented gases. Fractions of sodium, iron, and nickel released varied from 2.3 to $6.5 \%, 0.33$ to $0.59 \%$, and 0.45 to $0.80 \%$, respectively, for the $60{ }^{\circ} \mathrm{C}$ and the $120{ }^{\circ} \mathrm{C}$ initial temperature tests.

\section{ANALYSIS OF INITIAL FERROCYANIDE TANK WASTE SAMPLES}

Tank waste vertical core samples have been obtained and analyzed from tanks containing In Farm type waste (Tanks C-109 and C-112) and tanks containing T P1 ant type waste (Tanks TY-101 and TY-103). ${ }^{(9-12)}$ Key results of these anaiyses are 1 isted in Table 4. These results suggest that the ferrocyanide waste added to the tanks has mixed to some extent with other waste (higher nickel-bearing waste in Tank C-109 and lower nickel-bearing waste in Tanks $\mathrm{C}-112$, TY-101, and TY-103. The ferrocyanide concentration of the tank wastes is considerably lower than for the corresponding simulants. The heats of reaction, as measured by DSC for the tank waste, is also considerably less than the heats of reaction for the corresponding simulants. This suggests that the ferrocyanide waste was diluted by mixing with other waste, and ferrocyanide degradation by radiolysis or hydrolys is has occurred over the 35 plus years of storage. Studies are currently under way to evaluate the effects of radiolysis and possible hydrolysis in the presence of high $\mathrm{pH}$ waste. $(13,14)$

Samples from Tanks $C-109, C-112, T Y-101$, and TY-103 indicate that the free-water content of waste in these tanks is more than sufficient to preclude the occurrence of a propagating reaction for ferrocyanide concentrations as high as the most concentrated simulant. The nickel concentration of the waste as compared to the representative simulant is a general indicator of waste type mixing and resulting dilution of the ferrocyanide.

\section{CONCLUSIONS}

Simulants of ferrocyanide wastes have been characterized and evaluated along with initial tank waste samples to aid in establishing safety criteria for closure of the Ferrocyanide USQ and resolution of safety issues related to the ferrocyanide waste stored at the Hanford Site. Simulants were prepared to represent the three general types of ferrocyanide waste stored at the Hanford Site and tested for safety concerns. The simulants, as-prepared, were shown to not support propagation reactions that could spread to surrounding waste. A safety concern was identified, however, if the most concentrated simulants were allowed to be heated to high temperatures. Propagating reactions at rates up to $20 \mathrm{~cm} / \mathrm{min}$ were initiated by applying external heat to dried In Farm simulants. These reactions generated temperatures in excess of $1,200{ }^{\circ} \mathrm{C}$ and released gases and aerosols. Experimental limits of nonpropagation in bulk tank waste were determined to be a minimum 14 wt\% disodium 
Table 4. Key Safety Characteristics of Ferrocyanide Waste and Simulants.

\begin{tabular}{|c|c|c|c|c|}
\hline $\begin{array}{l}\text { Simulant } \\
\text { Tank/waste type }\end{array}$ & $\begin{array}{c}\text { Nickel } \\
\text { wt\% dry }\end{array}$ & $\begin{array}{l}\text { Total } \\
\text { cyanide } \\
\text { wt\% dry }\end{array}$ & $\begin{array}{l}\text { Heat of } \\
\text { reaction } \\
\mathrm{J} / \mathrm{g} \text { dry } \\
\text { waste } \\
\end{array}$ & $\begin{array}{c}\text { Free water } \\
\text { wt\% as } \\
\text { received }\end{array}$ \\
\hline $\begin{array}{l}\text { In Farm } 2 \\
\text { Tank C-109/ } \\
\text { In Farm and } \\
\text { other waste } \\
\text { Tank C-112/ } \\
\text { In Farm and } \\
\text { other waste }\end{array}$ & $\begin{array}{c}4.26 \\
10.8 \text { to } 30.9 \\
0.09 \text { to } 28.2 \\
\end{array}$ & $\begin{array}{c}10.2 \\
0.3 \text { to } 1.4 \\
0.4 \text { to } 0.97 \\
\end{array}$ & $\begin{array}{l}0 \text { to }-52 \\
0 \text { to }-36\end{array}$ & $\begin{array}{l}28.2 \text { to } 48.1 \\
39.3 \text { to } 56.8\end{array}$ \\
\hline $\begin{array}{l}\text { T Plant } \\
\text { Tank TY-101/ } \\
\text { T Plant and } \\
\text { other waste } \\
\text { Tank TY-103/ } \\
\text { T Plant and } \\
\text { other waste }\end{array}$ & $\begin{array}{c}0.51 \\
0.41 \text { to } 0.53\end{array}$ & 0.339 & $\begin{array}{l}-13.5 \\
-140\end{array}$ & 66.3 \\
\hline
\end{tabular}

mononickel ferrocyanide with zero free water. A minimum moisture content of 12 wt\% was needed to prevent propagating reactions for the more concentrated In Farm simulant with 25.6 wt\% disodium mononickel ferrocyanide.

Additional tank waste sampling and analysis are under way (starting with Tanks C-108 and C-111) to establish the expected low concentrations of ferrocyanide in the actual tank waste. Moisture retention studies with simulants are continuing to ensure that the moisture content of the waste is great enough to preclude uncontrolled ferrocyanide reactions for two In Farm waste tanks $(C-108$ and $C-111)$. Results of these ongoing studies are expected to support the classification of the ferrocyanide waste into the "safe" category.

\section{REFERENCES}

1. Postma, A. K., et al., 1994, Ferrocyanide Safety Program: Safety Criteria for Ferrocyanide Watch List Tanks, WHC-EP-0691, Westinghouse Hanford Company, Richland, Washington.

2. Cady, H. H., 1992, Evaluation of Ferrocyanide/Nitrate Explosive Hazard, LA-12589-MS, Los Alamos National Laboratory, Los Alamos, New Mexico.

3. Deaton, D. E., 1990, Unusual Occurrence-Unreviewed Safety Questions Regarding Tanks Containing Ferrocyanide, WHC-90-B003-R1, Update 10-22-90, Westinghouse Hanford Company, Richland, Washington. 
4. Borsheim, G. L., and B. C. Simpson, 1991, An Assessment of the Inventories of the Ferrocyanide Watch List Tanks, WHC-SD-WM-ER-133, Rev Westinghouse Hanford Company, Richland, Washington.

5. Fauske, H. K., 1992, Adiabatic Calorimetry and Reaction Propagation Tests with Synthetic Ferrocyanide Materials Including U Plant-1, U Plant-2, In Farm 1, In Farm 2, and Vendor-Procured Sodium Nickel Ferrocyanide, WHC-SD-WM-RDT-054, Rev. 0, Westinghouse Hanford Company, Richland, Washington.

6. Jeppson, D. W., and J. J. Wong, 1993, Ferrocyanide Waste Simulant Characterization, WHC-EP-0631, Westinghouse Hanford Company, Richland, Washington.

7. Burger, L. L., 1993, Calculation of Reaction Energies and Adiabatic Temperatures for Waste Tank Reactions, PNL-8557, Pacific Northwest Laboratory, Richland, Washington.

8. Burger, L. L., 1991, The Reactivity of Cesium Nickel Ferrocyanide Towards Nitrate and Nitrite Salts, PNL-7550, Pacific Northwest Laboratory, Richland, Washington.

9. Simpson, B. C., G. L. Borsheim, and L. Jensen, 1993, Tank Characterization Data Report: Tank 241-C-112, WHC-EP-0640, Rev. 1, Westinghouse Hanford Company, Richland, Washington.

10. Simpson, B. C., G. L. Borsheim, and L. Jensen, 1993, Tank Characterization Data Report: Tank 241-C-109, WHC-EP-0668, Westinghouse Hanford Company, Richland, Washington.

11. Grigsby, M. J., et al., 1992, Ferrocyanide Waste Tank Hazard Assessment Interim Report, WHC-SD-WM-RPT-032, Rev. 1, Westinghouse Hanford Company, Richland, Washington.

12. Beck, M. A., 1993, Analytical Test Results for Archived Core Composite Samples from Tanks 241-TY-101 and 241-TY-103, WHC-SD-WM-DTR-025, Rev. 0 , Westinghouse Hanford Company, Richland, Washington.

13. Babad, H., J. E. Meacham, B. C. Simpson, and R. J. Cash, 1993, The Role of Aging in Resolving the Ferrocyanide Safety Issue, WHC-EP-0599, Westinghouse Hanford Company, Richland, Washington.

14. Lilga, M. A., M. R. Lumetta, and G. G.Schiefelbein, 1993, Ferrocyanide Safety Project, Task 3 Aging Studies, FY 1993 Annual Report, PNL-8888, Pacific Northwest Laboratory, Richland, Washington. 
Figure 1. Schematic of Typical Ferrocyanide Single-Shell Tank With Waste.

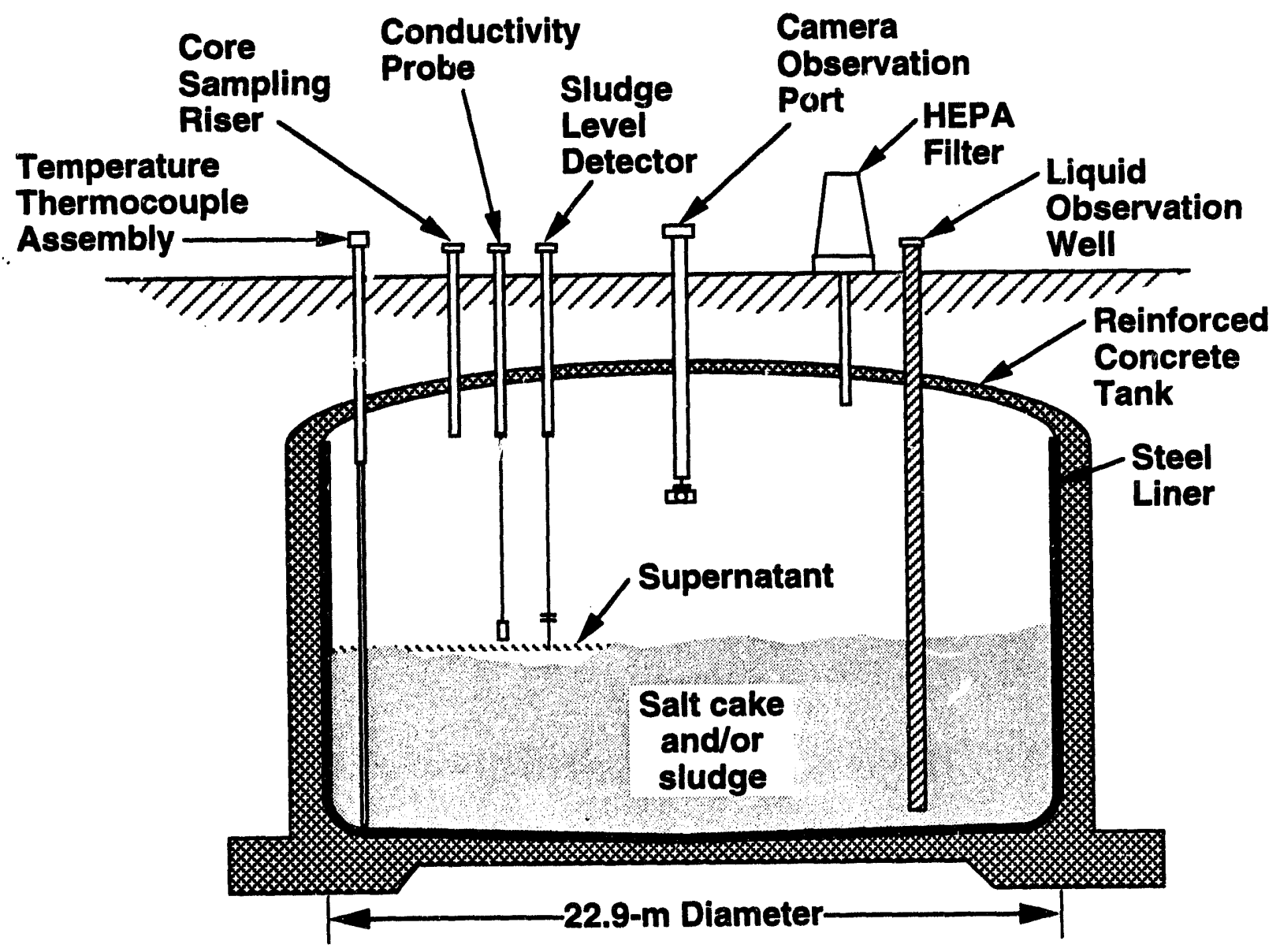

HEPA = high-efficiency particulate air (filter). 
Figure 2. Schematic of Propagation and Aerosol Test Equipment.

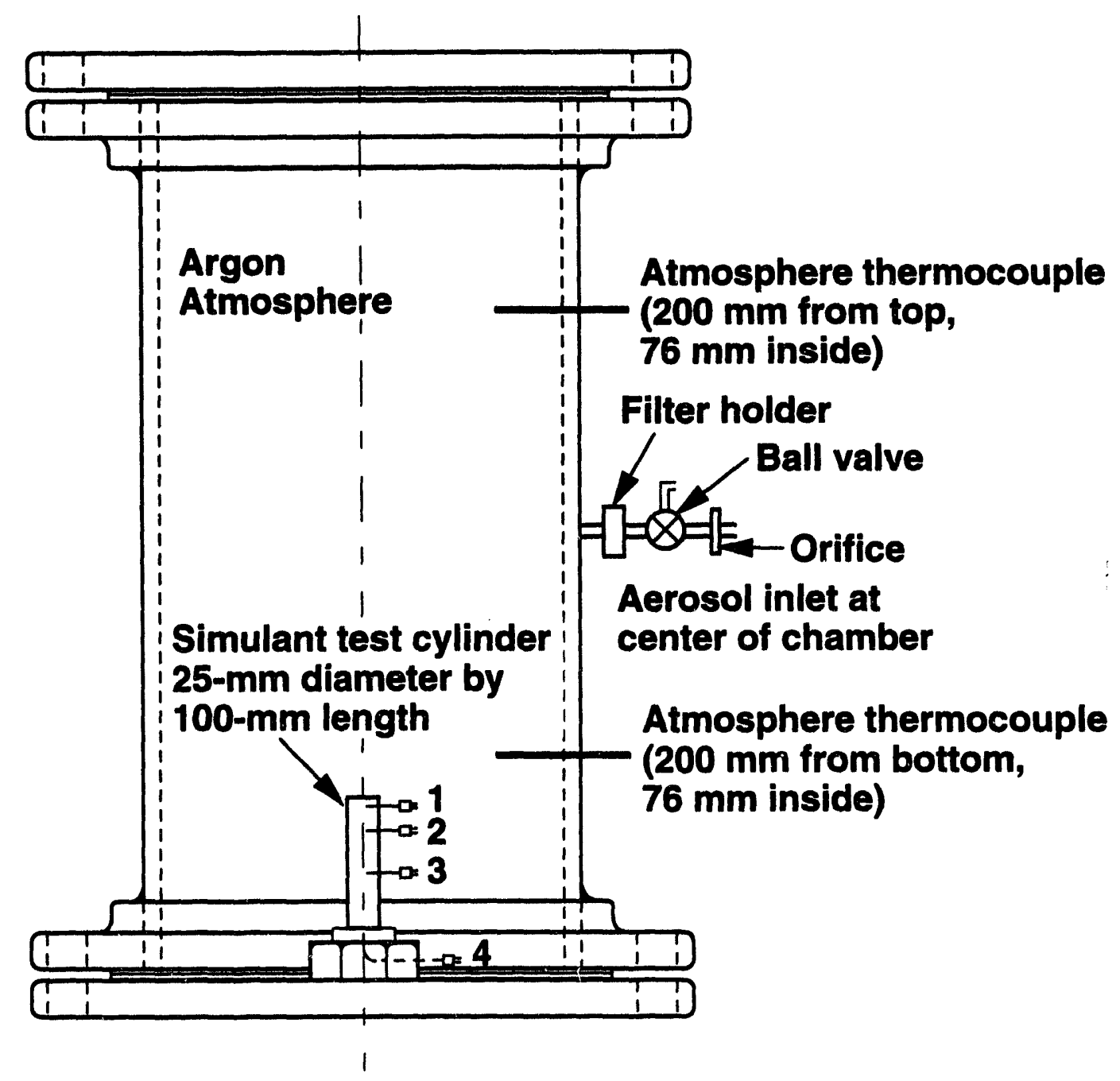

49-L vessel with 305- $\mathrm{mm}$ inside diameter by 9.6-mm-thick wall by $673-\mathrm{mm}$ length 
Figure 3. Experimental Propagation Limits as Functions of Ferrocyanide Concentration, Water Concentration, and Soltd Diluent Concentration.

- Adiabatic Calorimetry Test No Propagation

Propagation Rate Test No Propagation

$\triangle$ Propagation Rate Test Propagation Observed

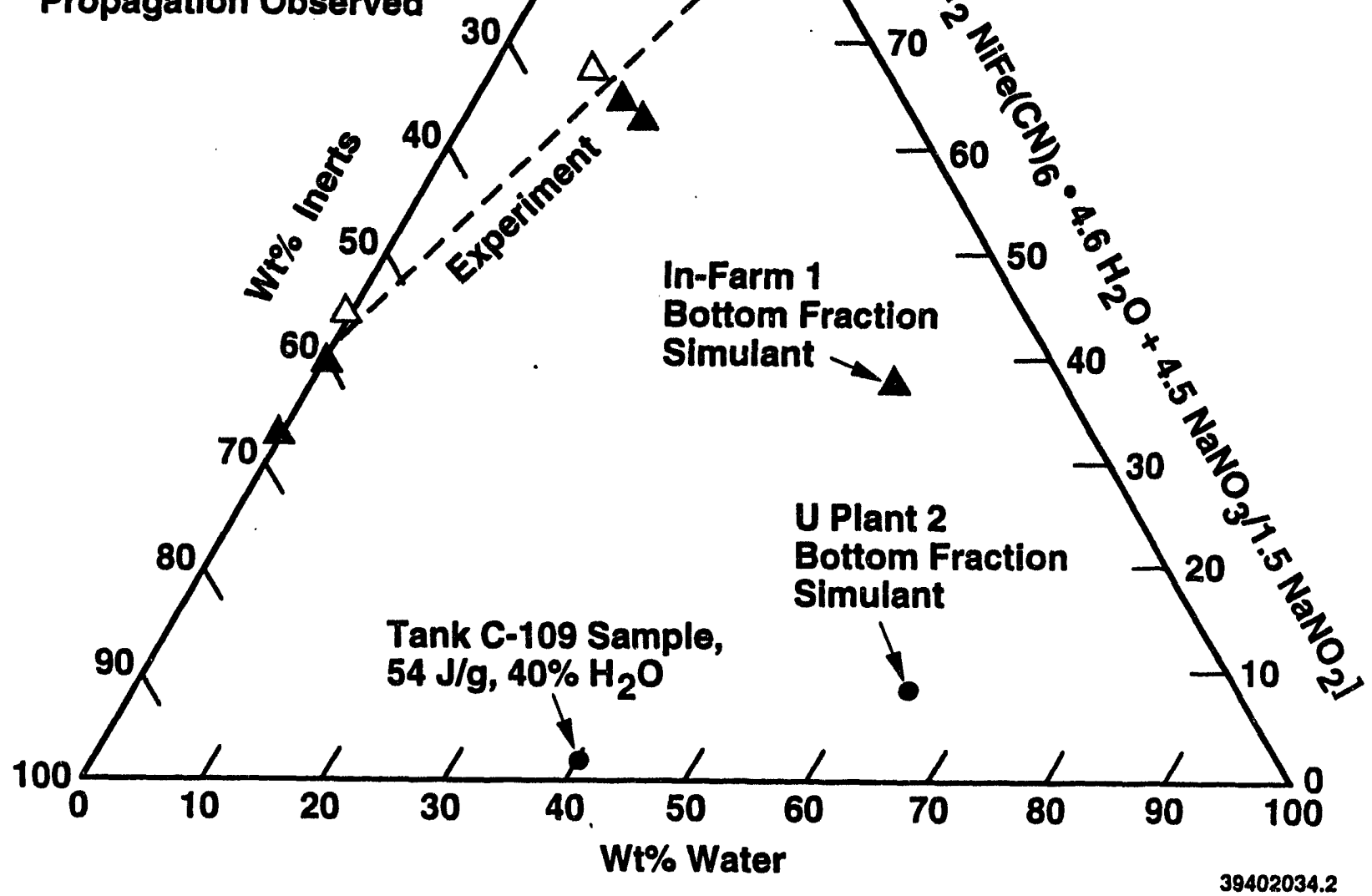


Figure 4. Propagation Rates for Dried In Farm 1 Bottom Fraction Simulant as Functions of Pressure and Initial Temperature.

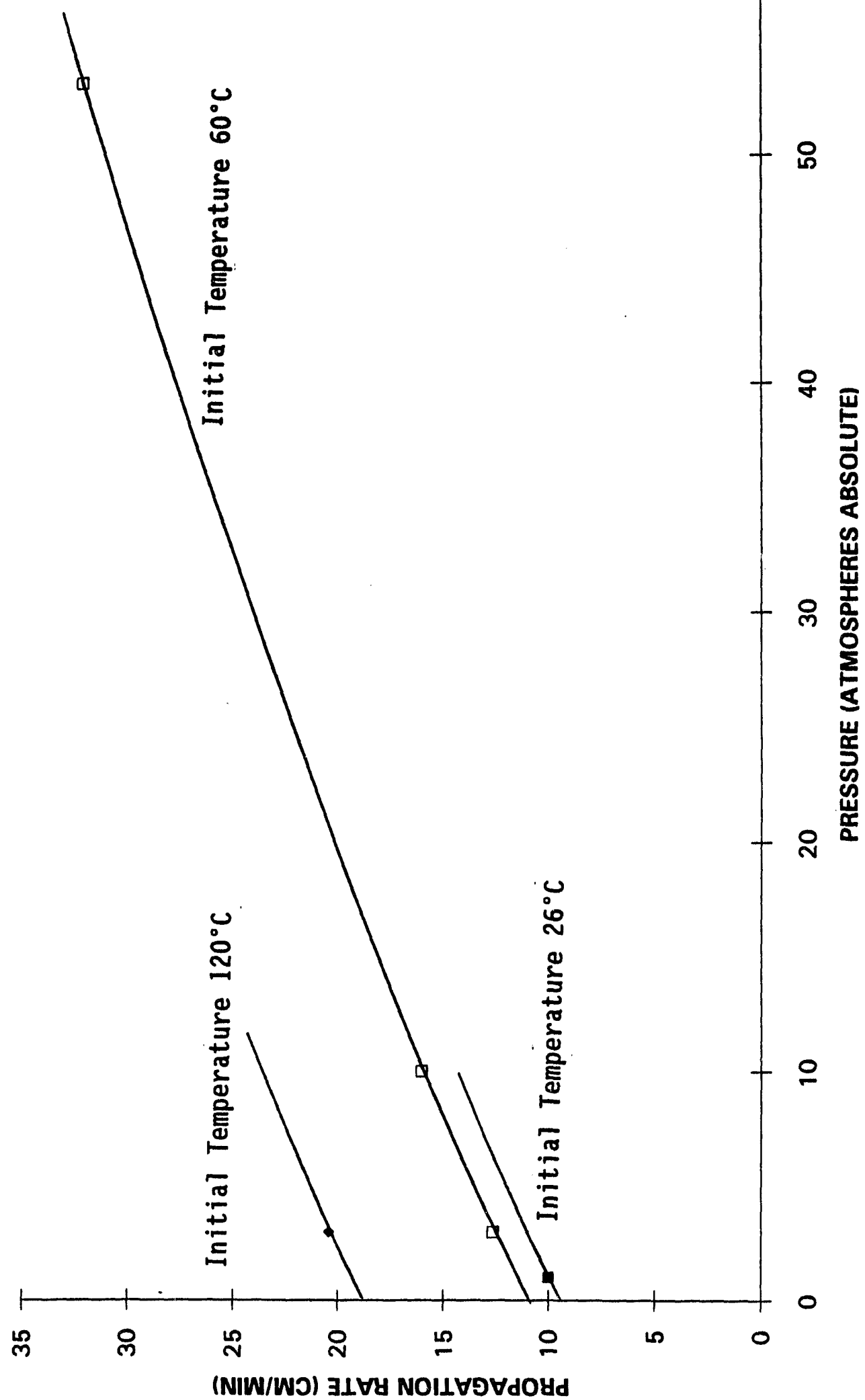




\section{DISTRIBUTION}

Number of Copies

OFFSITE

4

Laser Options. Inc.

245 South Plumer, Suite 19

Tucson, Arizona 85719

ATTN: Donna McComb

(4)

\section{ONSITE}

3

U.S. Department of Energy.

Richland Operations Office
R. F. Christensen
(3)
R3-72

21

Westinghouse Hanford Company
G. S. Barney
G. L. Borsheim
R. J. Cash
M. D. Crippen
J. M. Grigsby
J. A. Hunter
D. W. Jeppson (4)
J. D. McCormack
J. E. Meacham
A. K. Postma
B. C. Simpson (5)
Information Release
Administration (3)

T5-12

R2-11

R2-78

L5-31

H4-62

L5-31

L5-31

L5-31

R2-78

H4-62

R2-12

L8-07 
11

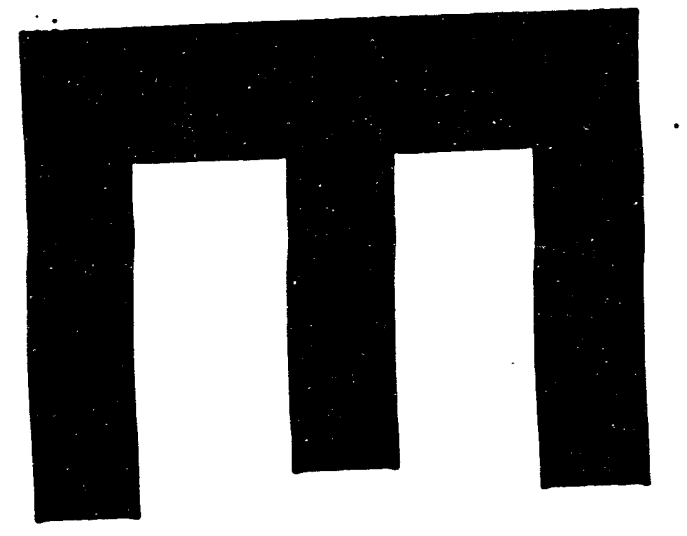

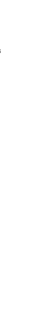
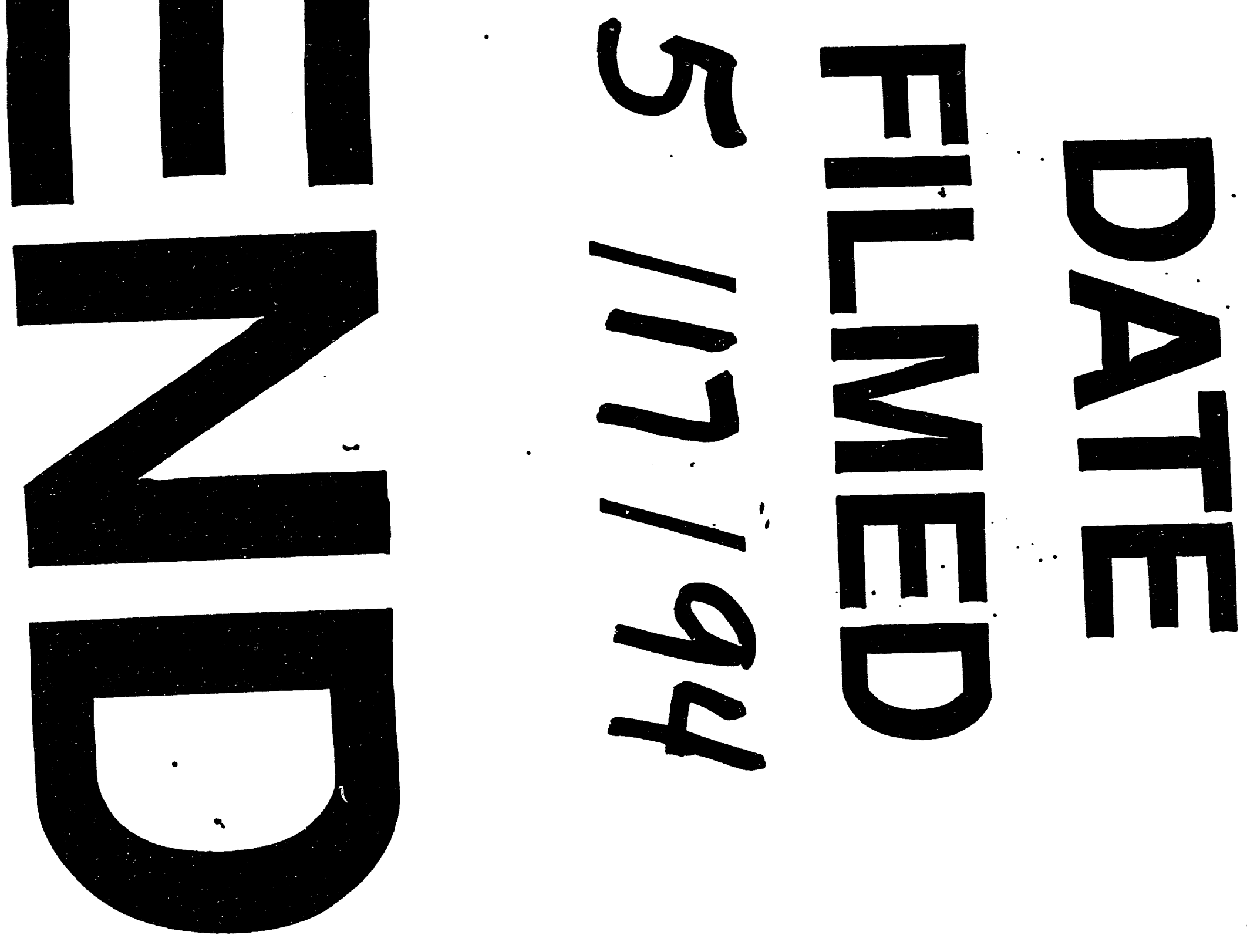
